\title{
KEWENANGAN MAHKAMAH KONSTITUSI SEBAGAI NEGATIVE LEGISLATOR DALAM PENGUJIAN UNDANG-UNDANG TERHADAP UNDANG-UNDANG DASAR 1945
}

\author{
Ika Kurniawati \\ Fakultas Hukum Universitas YARSI Jakarta \\ E-mail : ikkakurniawati0505@gmail.com \\ Lusy Liany \\ Fakultas Hukum Universitas YARSI Jakarta \\ E-mail: lusy.liany@yarsi.ac.id
}

\begin{abstract}
ABSTRAK
Mahkamah Konstitusi merupakan lembaga kekuasaan kehakiman yang salah satu kewenangannya menguji Undang-Undang terhadap UUD 1945. Perkembangannya, akhir-akhir ini terdapat beberapa putusan Mahkamah Konstitusi yang menjadi pro-kontra baik terkait hak uji materiil maupun hak uji formil. Pada putusan Mahkamah Konstitusi Nomor 1/PUU-XI/2013 yang amar putusannya mengubah isi Pasal 335 KUHP tentang perbuatan tidak menyenangkan menjadikan Mahkamah Konstitusi tidak dapat dipercaya lagi sebagai lembaga peradilan yang bersifat sebagai Negative Legislator. Tulisan ini diharapkan dapat menjadi bahan petimbangan pengusulan revisi terkait UU Mahkamah Konstitusi kepada Pemerintah dalam hal ini lembaga yang berwenang DPR dan Presiden serta Mahkamah Konstitusi terkait pengujian formil dan diharapkan kedepannya Mahkamah Konstitusi dalam hak uji materiil tetap berpedoman pada peraturan yang mengaturnya.
\end{abstract}

Kata Kunci: Negative Legislator, Materiil, Formil

\section{Abstract}

The Constitutional Court is an institution of judicial authority whose one of its authorities tests the Law against the 1945 Constitution. Its development, lately there have been several decisions of the Constitutional Court that have become pro-contra, both related to material test rights and formal test rights. In the decision of the Constitutional Court Number 1 / PUU-XI / 2013 whose decision to amend the contents of Article 335 of the Criminal Code concerning unpleasant actions made the Constitutional Court unable to be trusted as a judicial institution that is a Negative Legislator. This paper is expected to be a material consideration of the proposed revisions related to the Constitutional Court Law to the Government in this case the institution authorized by the DPR and the President and the Constitutional Court related to formal testing and it is expected that in the future the Constitutional Court in the judicial right remains guided by the regulations governing it.

Keywords: Negative Legislator, Materiil, Formil 


\section{PENDAHULUAN}

Sejarah berdirinya lembaga Mahkamah Konstitusi di Indonesia diawali dengan diadopsinya ide Mahkamah Konstitusi (Constitutional Court) dalam amandemen konstitusi yang dilakukan oleh MPR pada tahun 2001 sebagaimana dirumuskan dalam ketentuan Pasal 24 ayat (2), Pasal 24C, dan Pasal 7B UndangUndang Dasar 1945 hasil Perubahan Ketiga yang disahkan pada 9 November 2001. Setelah disahkannya Perubahan Ketiga Undang-Undang Dasar 1945 yang selanjutnya disebut UUD 1945 maka dalam rangka menunggu pembentukan Mahkamah Konstitusi, MPR menetapkan Mahkamah Agung melaksanakan fungsi dari Mahkamah Konstitusi untuk sementara sebagaimana diatur dalam Pasal III Aturan Peralihan Undang-Undang Dasar 1945 hasil Perubahan Keempat. ${ }^{1}$

Mahkamah Konstitusi, berdasarkan Pasal 24C ayat (1) dan ayat (2) UUD $1945^{2}$, mempunyai 4 (empat) kewenangan dan 1 (satu) kewajiban. Mahkamah Konstitusi berwenang mengadili pada tingkat pertama dan terakhir yang putusannya bersifat final untuk: (1) Menguji undang-undang terhadap UndangUndang Dasar 1945; (2) memutus sengketa kewenangan lembaga negara yang kewenangannya diberikan oleh UUD 1945; (3) memutus pembubaran partai politik; dan (4) memutus perselisihan tentang hasil pemilihan umum. Mahkamah Konstitusi wajib memberikan putusan atas pendapat DPR bahwa Presiden dan/atau Wakil Presiden diduga telah melakukan pelanggaran hukum berupa: penghianatan terhadap Negara, korupsi, penyuapan, tindak pidana lain, atau perbuatan tercela, dan/atau tidak lagi memenuhi syarat sebagai Presiden dan/atau Wakil Presiden sebagaimana yang dimaksud dalam UUD 1945. ${ }^{3}$ Di dalam penjelasan umum UU Nomor 8 Tahun 2011 Tentang Mahkamah Konstitusi disebutkan bahwa tugas dan fungsi Mahkamah Konstitusi adalah menangani perkara tertentu dibidang ketatanegaraan atau perkara konstitusional tertentu dalam rangka menjaga konstitusi agar dilaksanakan secara bertanggungjawab sesuai dengan kehendak rakyat dan cita-cita demokrasi. Selain itu keberadaan

\footnotetext{
${ }^{1}$ Nanang Sri Darmani, "Kedudukan dan Wewenang Mahkamah Konstitusi dalam Sistem Hukum Ketatanegaraan Indonesia", Jurnal Pembaharuan Hukum, vol. II, No. 2, Mei-Agustus 2015, hal. 261.

2 Indonesia (a), Undang-Undang Dasar Negara Republik Indonesia Tahun 1945, Pasal 24 ayat (1) dan ayat (2).

${ }^{3}$ Imam Soebechi, Hak Uji Materiil, cet. 1, (Jakarta: Sinar Gratifika, 2016), hal. 125.
} 
Mahkamah Konstitusi juga dimaksudkan sebagai koreksi terhadap pengalaman ketatanegaraan yang ditimbulkan oleh tafsir ganda atas konstitusi. ${ }^{4}$

Kehadiran Mahkamah Konstitusi dalam struktur ketatanegaraan Indonesia adalah dalam rangka mewujudkan sistem pemisahan kekuasaan (separation of power) dengan prinsip checks and balance. Dimana setiap cabang mengendalikan dan membagi kekuatan cabang kekuasaan yang lain, dengan harapan tidak terjadi penyalahgunaan kekuasaan tiap organ yang besifat independen. Pada dasarnya juicial review hanya dapat dijalankan sebagaimana mestinya dalam negara yang menganut supremasi hukum dan bukan supremasi parlemen. Dalam negara yang menganut sistem supremasi parlemen, produk hukum yang dihasilkan tidak dapat diganggu gugat, karena parlemen merupakan bentuk representasi dari kedaulatan rakyat. ${ }^{5}$ Hal ini sejalan dengan ajaran Trias Politica dari Montesquieu yang mengingatkan kekuasaan Negara harus dicegah agar jangan terpusat pada satu tangan atau lembaga. Pada ajaran Trias Politica tersebut, terdapat checks and balances yang berarti dalam hubungan antar lembaga negara dapat saling menguji atau mengoreksi kinerjanya sesuai dengan ruang lingkup kekuasaan yang telah ditentukan atau diatur dalam konstitusi.

Wewenang yang dimiliki Mahkamah Konstitusi untuk menguji undangundang terhadap UUD, sering disebut dengan istilah judicial review. Secara teoritik maupun praktek dikenal dua macam pengujian, yaitu pengujian formal (formale toetsingsrecht) dan pengujian secara materiil (materiele toetsingsrecht). Semua peraturan perundang-undangan yang dibentuk harus berdasar kepada UUD 1945 dan tidak boleh bertentangan dengan isi UUD 1945. Undang-undang yang bertentangan dengan UUD 1945 dapat dibatalkan melalui judicial review ke Mahkamah Konstitusi Republik Indonesia. ${ }^{6}$

Sri Soemantri menjelaskan bahwa yang dimaksud dengan hak menguji formil adalah wewenang untuk menilai, apakah suatu produk legislatif seperti undang-undang misalnya, terjelma melalui cara-cara (procedur) sebagaimana telah ditentukan/diatur dalam peraturan perundang-undangan yang berlaku

\footnotetext{
${ }^{4}$ Ibid., hal. 45.

${ }^{5}$ Nanang Sri Darmani, op. cit., hal. 259.

${ }^{6}$ Eko Supriyanto, "Kedudukan Naskah Akademik dalam Penafsiran Ketentuan-Ketentuan dalam Undan-Undang”, Yuridika, vol. 31, No. 3, September 2016, hal. 385.
} 
ataukah tidak. Sedangkan, Harun Alrasid mengemukakan bahwa hak menguji formal ialah mengenai prosedur pembentukan UU. ${ }^{7}$ Pasal 51 ayat (3) huruf a UU Nomor 8 Tahun 2011 Tentang Mahkamah Konstitusi mengatur mengenai pengujian formil, dimana dalam ketentuan tersebut diatur bahwa Pemohon wajib menguraikan dengan jelas bahwa pembentukan Undang-Undang tidak memenuhi ketentuan berdasarkan UUD 1945.

Dalam Pasal 1 angka 3 Undang-Undang Nomor 12 Tahun 2011 yang selanjutnya disebut UU Nomor 12 Tahun 2011 Tentang Pembentukan Peraturan Perundang-undangan diatur bahwa: "Undang-Undang adalah Peraturan Perundang-undangan yang dibentuk oleh Dewan Perwakilan Rakyat dengan pesetujuan bersama Presiden. ${ }^{8}$ Seperti yang terdapat dari beberapa putusan Mahkamah Konstitusi yang kewenangannya menguji materiil yaitu Putusan Mahkamah Konstitusi Nomor 1/PUU-XI/2013, Putusan Mahkamah Konstitusi Nomor 3/PUU-XI/2013, Putusan Mahkamah Konstitusi Nomor 46/PUUXIV/2016 dan pengujian formil pada putusan Mahkamah Konstitusi Nomor 27/PUU-VII/2009 dan putusan Mahkamah Konstitusi Nomor 018/PUU-I/2003. Masing-masing dari putusan tersebut menerangkan putusan Mahkamah Konstitusi yang berbeda-beda.

Pada putusan Mahkamah Konstitusi Nomor 1/PUU-XI/2013, pengujian Pasal 335 ayat (1) Kitab Undang-undang Hukum Pidana yang selanjutnya disebut KUHP dan Pasal 21 ayat (4) Kitab Undang-undang Hukum Acara Pidana yang selanjutnya disebu KUHAP bertentangan dengan Pasal 28D UUD 1945. Putusan Hakim dalam perkara ini yaitu mengabulkan permohonan pemohon untuk sebagian dan menyatakan perubahan sebagian frasa dalam pasal 335 ayat (1) butir 1 KUHP. $^{9}$

Dalam putusan Mahkamah Konstitusi Nomor 3/PUU-XI/2013 yang mengadili perkara pengujian Undang-Undang Nomor 8 Tahun 1981 tentang KUHAP terhadap Pasal 27 ayat (1) dan Pasal 28D ayat (1) UUD 1945. Dimana Pasal 18 ayat (3) KUHAP tidak mengatur tentang pemaknaan tentang berapa lama

${ }^{7}$ Ibid., hal. 92

8 Janedri M. Gaffar, Hukum Acara Mahkamah Konstitusi, cet. I, (Jakarta: Sekretariat Jendera dan Kepaniteraan MKRI, 2011), hal. 91-92.

9 Mahkamah Konstitusi Republik Indonesia (a), "Putusan Nomor: 1/PUU-XI/2013". 
kata "segera" sehingga Penyidik Kepolisian Republik Indonesia maupun. Putusan Hakim yaitu mempersempit makna kata "segera" menjadi "segera dan tidak lebih dari 7 (tujuh) hari”. Menurut Hakim, walaupun seseorang warga Negara telah ditetapkan sebagai tersangka atas suatu perbuatan tindak pidana, tetap saja warga tersebut memiliki hak konstitusional yang dijamin oleh UUD $1945^{10}$

Dalam putusan Mahkamah Konstitusi Nomor 46/PUU-XIV/2016, pemohon merupakan beberapa aktifis dibidang pengejar dan aktifis dibidang HAM yang menurut Hakim Mahkamah Konstitusi memiliki legal standing dalam permohonan uji materiil Pasal Perzinahan, Pasal Pemerksaan dan Pasal Pencabulan terhadap beberapa Pasal dalm UUD 1945. Putusan Hakim dalam perkara ini yaitu menolak keseluruhan permohonan pemohon. Beberapa Hakim berbeda pendapat (dissenting opinion). Menurut beberapa Hakim jika permohona pemohon dikabulkan maka MK akan melewati batas kewenangannya. Namun beberap Hakim juga berpendapat bahwa MK juga berwenangan mengadili dan dapat mengabulkan Permohonan pemohon. ${ }^{11}$

Pada putusan Mahkamah Konstitusi Nomor 27/PUU-VIII/2009, para Pemohon mengajukan pengujian formil Undang-Undang Nomor 3 Tahun 2009 tentang Perubahan Atas Undang-Undang Nomor 5 Tahun 2004 tentang Perubahan Atas Undang-Undang Nomor 14 Tahun 1985 Tentang Mahkamah Agung terhadap Pasal 20 ayat 1, Pasal 20A ayat 1, Pasal 22A dan Pasal 1 ayat 3 UUD 1945. Dalam perkara ini pemohon mempermasalahkan prosedur pembentukan Undang-undang yang akan diujikan tersebut, menurut Pemohon banyak prosedur yang bertentangan saat pembentukan Undang-undang tersebut. Menurut pertimbangan Hakim Pengujian formil tersebut diajukan karena terdapat cacat prosedural dalam pembentukan, namun demi asas kemanfaatan hukum UndangUndang tersebut tetap berlaku. ${ }^{12}$

Selanjutnya, pada putusan Mahkamah Konstitusi lainnya mengenai pengujian Formil Undang-Undang yaitu Putusan Mahkamah Konstitusi Nomor 018/PUU-I/2003 yang mengajukan Permohonan Pengujian Undang-undang

\footnotetext{
${ }^{10}$ Mahkamah Konstitusi Republik Indonesia (b), "Putusan Nomor: 3/PUU-XI/2013"

11 Mahkamah Konstitusi Republik Indonesia (c), "Putusan Nomor: 46/PUU-XIV/2016".

12 Mahkamah Konstitusi Republik Indonesia (d), "Putusan Nomor: 27/PUU-VII/2009”.
} 
Nomor 45 Tahun 1999 tentang Pembentukan Propinsi Irian Jaya Tengah, Propinsi Irian Jaya Barat, Kabupaten Paniai, Kabupaten Mimika, Kabupaten Puncak Jaya, dan Kota Sorong, diubah dengan Undang-undang Nomor 5 Tahun 2000 tentang Perubahan atas Undang-undang Nomor 45 Tahun 1999 tentang Pembentukan Propinsi Irian Jaya Tengah, Propinsi Irian Jaya Barat, Kabupaten Paniai, Kabupaten Mimika, Kabupaten Puncak Jaya, dan Kota Sorong, bertentangan dengan Pasal 18B UUD 1945 dimana Amar Putusan Mahkamah Konsitutsi Mengabulkan Permohonan Pemohon. ${ }^{13}$ Dengan pertimbangan para hakim bahwa untuk mengakhiri ketidakpastian hukum serta mencegah timbulnya konflik dalam masyarakat.

Pro-kontra kewenangan Mahkamah Konstitusi dalam menguji undangundang terhadap Undang-Undang dasar telah banyak menyita perhatian masyarakat. Mahkamah Konstitusi yang dianggap Peradilan yang final dan bersih tidak lagi dianggap sejalan dengan eksistensinya. Terdapat putusan yang tidak sesuai dengan kewenangan yang terdapat dalam Pasal 57 UU Nomor 8 Tahun 2011 Tentang Mahkamah Konstitusi dan Pasal 36 PMK Nomor: 06/PMK/2005 Tentang Pedoman Beracara dalam Perkara Pengujian Undang-Undang. Berdasarkan latar belakang permasalahan yang penulis ungkapkan, maka dapat ditarik beberapa rumusan masalah sebagai berikut. Pertama, Bagaimana Kewenangan Mahkamah Konstitusi dalam menguji materiil Undang-undang terhadap Undang-Undang Dasar 1945 (UUD 1945)? Kedua, Bagaimana Kewenangan Mahkamah Konstitusi dalam menguji formil Undang-undang terhadap Undang-Undang Dasar 1945 (UUD 1945) ?

\section{METODE PENELITIAN}

Jenis penelitian yang digunakan oleh penulis dalam penyusunan penulisan ini adalah penelitian hukum yuridis normatif. Penelitian yang biasa disebut dengan pendekatan perundang-undangan (Statute Approach) pendekatan kasus (Case Approach), dan pendekatan konseptual (Conceptual Approach) ${ }^{14}$ yang

2.

${ }^{13}$ Mahkamah Konstitusi Republik Indonesia(e), "Putusan Nomor : 018/PUU-I/2003”, hal.

${ }^{14}$ Peter Mahmud Marzuki, Penelitian Hukum, (Jakarta: Prenadamedia Group, 2016), hal 136. 
mana penelitian terhadap bahan pustaka atau menggunakan data sekunder. ${ }^{15}$ Penelitian yang dilakukan adalah bersifat deskriptif. Dalam melakukan penelitian ini, sumber data yang penulis gunakan adalah dengan menggunakan data sekunder, yang terdiri dari bahan hukum primer, berupa peraturan perundangundangan yang terkait dengan penelitian antara lain yaitu, UUD NRI Tahun 1945, UU Nomor 8 Tahun 2011 Tentang MK, PMK Nomor 06 Tahun 2005 Tentang Pedoman Beracara Perkara Pengujian UU, Putusan MK Nomor: 1/PUU-XI/2013, Putusan MK Nomor: 3/PUU-XI/2013, Putusan MK Nomor: 46/PUU-XIV/2016, Putusan MK Nomor: 27/PUU-VII/2009. dan Putusan MK Nomor : 018/PUUI/2003. Putusan Mahkamah Konstitusi, Putusan Nomor 56/PUU-XIV/2016, bahan hukum sekunder berupa semua publikasi tentang hukum yang bukan merupakan dokumen-dokumen resmi. Publikasi tentang hukum meliputi buku-buku teks, kamus-kamus hukum, jurnal-jurnal hukum dan komentar-komentar atas putusan Pengadilan; ${ }^{16}$ dan bahan hukum tersier berupa bahan yang memberikan petunjuk maupun penjelasan terhadap bahan hukum primer dan bahan hukum sekunder. Dalam hal ini, yang digunakan oleh penulis adalah berupa kamus dan berbagai sumber dari situs internet.

\section{PEMBAHASAN}

\section{Kewenangan Mahkamah Konstitusi dalam Menguji Materiil Undang- undang terhadap Undang-Udang Dasar 1945 (UUD 1945)}

Salah satu pelaksanaan kewenangan Mahkamah Konstitusi yang ditentukan oleh UUD 1945 yaitu pengujian undang-undang terhadap UUD 1945 (judicial review). Dimana dalam melakukan pengujian tersebut, Mahkamah Konstitusi menyandarkan frasa pasal, ayat dalam pasal, pasal maupun keseluruhan pasal dari undang-undang yang diuji tersebut dengan UUD 1945. Mahkamah Konstitusi yang disebut juga sebagai "the guardian of constitution and the sole interpreting of constitution." Disebut sebagai penjaga konstitusi berdasarkan kewenangan dalam memutus apakah sebuah produk perundang-undangan telah

15 Soerjono Soekanto, Pengantar Penelitian Hukum, cet 3, (Jakarta : Universitas Indonesia, 2014), hal. 42.

${ }^{16}$ Peter Mahmud Marzuki, op. cit., hal. 181. 
sesuai dengan konstitusi atau tidak. ${ }^{17}$ Kemudian disebut sebagai satu-satunya lembaga yang dapat menafsirkan konstitusi dikarenakan kewenangan judicial review menciptakan kewenangan tersebut. Kewenangan menafsirkan itu timbul dari sebuah tafsir pula bahwa bagaimana bisa melakukan review terhadap sebuah undang-undang agar berkesesuaian dengan konstitusi apabila tidak diberi kewenangan memaknai dan menafsirkan konstitusi itu sendiri. Artinya kewenangan tafsir konstitusi itu lahir juga dari sebuah penafsiran. ${ }^{18}$

Diakuinya hak menguji (judicial review) di Indonesia menurut Jimly Asshiddiqie merupakan upaya pengujian oleh lembaga judicial terhadap produk hukum yang ditetapkan oleh cabang kekuasaan legislatif, eksekutif, atau yudikatif. Pemberian kewenangan kepada hakim tersebut merupakan penerapan prinsip checks and balance berdasarkan sistem pemisahan kekuasaan negara yang dapat dipercaya lebih menjamin perwujudan gagasan demokrasi dan cita negara hukum Rechtsstaat atau Rule of Law. Sesuai dengan prinsip checks and balances yang telah menjadi salah satu pokok pikiran dalam UUD 1945 pasca perubahan, pengujian konstitusionalitas materi undang-undang telah ditegaskan menjadi kewenangan hakim, yaitu Mahkamah Konstitusi. ${ }^{19}$

Pengujian terhadap norma undang-undang adalah pengujian mengenai nilai konstitusionalitas undang-undang, baik dari segi formil ataupun materiil. Karena itu, pada tingkat pertama, pengujian konstitusionalitas haruslah dibedakan dari pengujian legalitas. Mahkamah Konstitusi pengujian konstitusionalitas, sedangkan Mahkamah Agung melakukan pengujian legalitas, bukan pengujian konstitusionalitas. ${ }^{20}$ Dalam perkara judicial review undang-undang, baik menurut UUD 1945 maupun menurut UU Mahkamah Konstitusi, ditegaskan Mahkamah Konstitusi hanya berwenang menilai atau mengadili konstitusionalitas sebuah UU terhadap UUD 1945. Mahkamah Konstitusi hanya dapat menyatakan apakah sebuah UU, sebagian isinya, kalimat, atau frasanya, bertentangan dengan

17 Anonimous, "Eksistensi Lembaga Negara, Berdasarkan UU Negara RI Tahun 1945", Jurnal Legislasi, Vol. 4, No. 3, Direktorat Jenderal Peraturan Perundang-undangan Departemen Hukum dan HAM RI, Jakarta 2007, hal. 72.

18 Jimly Asshiddiqie, Setengah Abad Jimly Asshiddiqie, Konstitusi dan Semangat Kebangsaan, (Jakarta: PT. Sumber Agung, 2006), hal. 37.

${ }^{19}$ Ibid., hal. 137

20 Jimly Asshiddiqie, Hukum Acara Pengujian Undang-Undang, Cet. 2, (Jakarta: Sekretariat Jenderal dan Kepaniteraan Mahkamah Konstitusi RI, 2006), hal .5-6 
konstitusi atau tidak. Mahkamah Konstitusi tidak dapat menerobos batas kompetensi konstitusionalitas dan masuk ke dalam kompetensi legalitas. Dalam perkara judicial review, amar putusan Mahkamah Konstitusi tidak dapat masuk ke ranah yang bersifat legalitas. ${ }^{21}$

Terhadap hak uji materil, Sri Soemantri, memberikan garis bawah bahwa pengujian tersebut adalah suatu wewenang untuk menyelidiki dan kemudian menilai, apakah suatu peraturan perundang-undangan isinya sesuai atau bertentangan dengan peraturan yang lebih tinggi derajatnya, serta apakah suatu kekuasaan tertentu (verordenende macht) berkah mengeluarkan suatu peraturan tertentu. ${ }^{22}$ Karakteristik khusus dalam pengujian materiil undang-undang terhadap UUD 1945 adalah adanya penggunaan tolok ukur metode penafsiran oleh hakim konstitusi untuk menilai materi atau substansi UUD 1945. Penggunaan metode penafsiran oleh hakim konstitusi untuk menilai pertentangan norma hukum dilandasi bahwa Mahkamah Konstitusi merupakan satu-satunya lembaga negara sebagai penafsir konstitusi (the sole judicial interpreter of the constitution). Pengujian konstitusionalitas (pengujian materiil) tidak dapat dilaksanakan tanpa kewenangan menafsirkan pasal-pasal dalam konstitusi yang memiliki kekuatan hukum. Prinsip dasar keadilan konstitusi tidak dapat tercapai apabila masingmasing cabang kekuasaan diberikan kekuasaan untuk menginterpretasikan konstitusi sesuai dengan interpretasinya sendiri-sendiri. ${ }^{23}$

Penafsiran merupakan bagian dari rechtsvinding (penemuan hukum) yang selalu dilakukan oleh hakim dalam memeriksa dan mengadili perkara. ${ }^{24}$ Besarnya kewenangan tafsir tidak terlepas dari upaya untuk memenuhi rasa keadilan, namun jika kewenangannya tersebut tidak dapat digunakan secara negarawan, maka

21 Muhammad Mahrus Ali, "Konstitusional dan Legalitas Norma dalam Pengujian Undang-Undang Terhadap Undang-Undang Dasar 1945", Jurnal Konstitusi, vol. 12, No. 1, Maret 2015, hal. 176.

${ }^{22}$ Sri Soemantri, Hak Menguji Material di Indonesia, (Bandung: Penerbit Alumni,1986), hal. 6 .

23 Abdul Latief, Fungsi Mahkamah Konstitusi: Upaya Mewujudkan Negara Hukum Demokrasi, (Yogyakarta: Total Media, 2009), hal. 323-324.

24 Mukti Arto, Konsepsi Ideal Mahkamah Agung: Redefenisi Peran dan Fungsi Mahkamah Agung untuk Membangun Indonesia Baru, (Yogyakarta: Pustaka Pelajar, 2001), hal. 332. 
dapat saja merugikan masyarakat pencari keadilan. ${ }^{25}$ Menurut Satjipto Rahardjo bahwa penafsiran hukum itu merupakan jantung hukum, hampir tidak mungkin hukum bisa dijalankan tanpa membuka pintu penafsiran. Penafsiran hukum merupakan aktifitas yang mutlak terbuka untuk dilakukan, sejak hukum berbentuk tertulis. Diajukan sebuah adagium "membaca hukum adalah menafsirkan hukum", mengatakan teks hukum sudah jelas, adalah suatu cara saja bagi pembuat hukum untuk bertindak pragmatis seraya diam-diam mengakui, bahwa ia mengalami kesulitan untuk memberikan penjelasan. ${ }^{26}$ Artinya kewenangan MK dalam menafsirkan konstitusi sangat besar, bahkan kewenangan MK dalam menafsirkan konstitusi dapat saja memasuki wilayah tanpa batas.

John H. Garvey dan Alexander Aleinikoff mengemukakan beberapa metode utama dalam melakukan penafsiran konstitusi, yaitu: Interpretivism/NonInterpretivism, Textualism, Original Intent, Stare Decisis, Neutral Principles dan balancing atau kombinasi dari beberapa metode tersebut. Para hakim menggunakan pandangan atau kemampuan mereka berdasarkan pemahaman mereka terhadap hukum itu sendiri, artinya bahwa hakim-hakim berbeda pula dalam melakukan penafsiran konstitusi, sehingga suatu saat para hakim akan saling bertentangan dalam menafsirkan konstitusi terhadap sebuah perkara tertentu. Penafsiran Original Intent merupakan penafsiran yang sesuai dengan pengertian asli dari teks atau istilah-istilah yang terdapat didalam konstitusi. Penafsiran ini biasanya digunakan untuk menjelaskan teks, konteks, tujuan, dan struktur konstitusi. $^{27}$

Penafsiran originalis ini menitikberatkan pada penilaian pertentangan norma hukum berdasarkan pada original meaning atau original intent yaitu mencoba menghadirkan semangat awal terbentuknya konstitusi tertulis lewat perdebatan-perdebatan pada saat penyusunan UUD, mendasarkan pada pemahaman dan tujuan konstitusi dari pendapat para penyusun konstitusi, originalis melihat beberapa sumber diantaranya pandangan framers of constitution

\footnotetext{
${ }^{25}$ Refli Harun, Menjaga Denyut Konstitusi (Refleksi Satu Tahun Mahkamah Konstitusi), (Jakarta: Konstitusi Press, 2004), hal. 301.

${ }^{26}$ Feri Amsari, "Satjipto Rahardjo dalam Jagat Ketertiban Hukum Progresif" Jurnal Konstitusi, vol. 6, No. 2, Juli 2009, hal. 180.

${ }_{27}$ Syawaluddin Hanafi, "Kewenangan Mahkamah Konstitusi dalam Menafsir UndangUndang Dasar Negara Republik Indonesia Tahun 1945", Ekspose, vol. XXVI, No. 1, Januari-Juni 2017, hal. 7
} 
termasuk tulisan-tulisan terdahulu pada penyusun konstitusi, artikel-artikel pada koran ketika konstitusi dibentuk, notulensi persidangan dalam pembentukan konstitusi, misalnya catatan persidangan BPUPKI dalam pembentukan UUD 1945, cacatan-catatan perumusan norma UUD 1945 amandemen. Justice Antonin Scalia (Hakim Agung Supreme Court Amerika) yang menganut pandangan originalis berpendapat bahwa penafsiran konstitusi hanya dapat dilakukan melalui pendekatan pemahaman dari penyusun konstitusi itu sendiri atau pemahaman umum dari masyarakat terhadap konstitusi itu sendiri. Para originalis mempercayai bahwa cara terbaik dalam menafsirkan konstitusi adalah dengan melihat tujuan para penyusun konstitusi itu sendiri. ${ }^{28}$

Menurut Mahfud MD, bahwa ketidakjelasan tolok ukur dalam memaknai pertentangan norma hukum yang berdasarkan pada pemaknaan, kriteria, penggunaan penafsiran original intent sebagai metode penafsiran dalam pengujian norma hukum, hal ini terkait dengan teori apa yang menjadi dasar dan semangat dalam perumusan konstitusi maupun pembentukan peraturan perundangundangan. Hakim boleh menggunakan original intent suatu produk hukum, hal ini berdasarkan fakta bahwa secara teoritis pengujian norma hukum tersebut bertujuan untuk mengetahui makna atau maksud utama/maksud sebenarnya dari isi konstitusi atau peraturan perundang-undangan. ${ }^{29}$ Sebab dengan pemahaman original intent, maka orisinilitas ataupun gagasan dan semangat asli dari suatu rumusan peraturan perundang-undangan dapat terlindungi. Pengujian dilakukan karena pertentangan antara isi undang-undang dengan UUD, dimana isi konstitusi suatu negara adalah apa yang ditulis dan latar belakang pemikiran apa yang melahirkan tulisan isi konstitusi tersebut tanpa harus terikat dengan teori dan apa yang berlaku di negara lain. ${ }^{30}$ Selain itu, Mahkamah Konstitusi harus menjadikan original intens sebagai tolok ukurnya. ${ }^{31}$

Penafsiran non originalis (non original intent). Berbeda dengan penafsiran originalis, alasan yang kuat bahwa penggunaan penafsiran non originalis (non

\footnotetext{
${ }^{28}$ Saldi Isra, Pergeseran Fungsi Legislasi: Menguatnya Model Legislasi Parlementer Dalam Sistem Presidensial Indonesia, (Jakarta: Rajawali Press, 2010), hal. 58.

${ }^{29}$ Moh Mahfud MD, Perdebatan Hukum Tata Negara Pasca Amandemen Konstitusi, (Jakarta: Rajawali Pers, 2010), hal. 65.

30 Saldi Isra, op.cit., hal. 58.

31 Moh Mahfud MD, Konstitusi dan Hukum dalam Kontroversi Isu, (Jakarta: Rajawali Pers, 2009), hal. 208.
} 
original intent) oleh hakim merupakan penafsiran yang paling tepat dalam memahami konstitusi sekaligus sebagai dasar menentukan pertentangan norma hukum adalah:

a) Para perancang konstitusi (pada konvensi Philadelphia) mengindikasikan bahwa mereka tidak ingin keinginan-keinginan mereka yang bersifat spesifik nantinya akan mengontrol interpretasi;

b) Tidak ada satupun konstitusi tertulis yang mampu mengantisipasi caracara yang dapat digunakan pemerintah di masa yang akan datang untuk menindas rakyat, sehingga ada kalanya merupakan keharusan bagi hakim untuk mengisi kekosongan itu;

c) Maksud para perancang itu bermacam-macam, terkadang bahkan sifatnya sementara dan seringkali mustahil untuk ditentukan;

d) Non originalisme memungkinkan hakim untuk mencegah krisis yang dapat terjadi karena penafsiran yang tidak fleksibel terhadap suatu ketentuan dalam konstitusi yang tidak lagi mampu memenuhi maksud asli dari ketentuan itu; dan

e) Non originalisme memungkinkan konstitusi berkembang sesuai dengan pengertian-pengertian yang lebih mencerahkan tentang hal-hal, seperti perlakuan yang sama terhadap orang-orang (kulit hitam), kaum perempuan, dan kaum minoritas lainnya. ${ }^{32}$

Penafsiran non originalis memberikan pemahaman bahwa lembaga kekuasaan kehakiman Mahkamah Konstitusi sebagai lembaga penafsir UndangUndang Dasar (the sole judicial interpreter of the constitution) tidak boleh hanya semata-mata terpaku kepada metode penafsiran "originalisme" dengan mendasarkan diri hanya kepada "original intent" perumusan pasal UUD 1945, terutama apabila penafsiran demikian justru menyebabkan tidak bekerjanya ketentuan-ketentuan UUD 1945 sebagai suatu sistem dan/atau bertentangan dengan gagasan utama yang melandasi UUD itu sendiri secara keseluruhan berkaitan dengan tujuan yang hendak diwujudkan. Mahkamah Konstitusi harus memahami UUD 1945 dalam konteks keseluruhan jiwa (spirit) yang terkandung

${ }^{32}$ I Dewa Gede Palguna, Mahkamah Konstitusi: dasar pemikiran, kewenangan, dan perbandingan dengan negara lain, (Sekretariat Jenderal MK RI:Konstitusi Press (Konpress), 2018. 
di dalamnya guna membangun kehidupan ketatanegaraan yang lebih tepat dalam upaya memadukan cita hukum (rechtsidee) dan cita negara (staatsidee) guna mewujudkan negara hukum yang demokratis dan negara demokrasi yang berdasar atas hukum, yang merupakan penjabaran pokok pikiran yang terkandung dalam Pembukaan UUD 1945. ${ }^{33}$

\section{Berikut Perbandingan Putusan Mahkamah Konstitusi dalam Menguji Materiil Undang-Undang terhadap Undang-Undang Dasar 1945: \\ 1) Putusan Mahkamah Konstitusi Nomor: 1/PUU-XI/2013}

Terkait kewenangan Mahkamah Konstitusi dalam menafsirkan UUD 1945, telah terjadi dan diputuskan melalui Putusan Mahkamah Konstitusi Nomor 1/PUU-XI/2013 yang menyatakan mengabulkan permohonan pemohon untuk sebagian. Dalam amar putusannya Mahkamah Konstitusi Pasal 335 ayat (1) butir 1 Undang-Undang Nomor 1 Tahun 1946 tentang Peraturan Hukum Pidana atau Kitab Undang-Undang Hukum Pidana juncto Undang-Undang Republik Indonesia Nomor 73 Tahun 1958 tentang "Barang siapa secara melawan hukum memaksa orang lain supaya melakukan, tidak melakukan atau membiarkan sesuatu, dengan memakai kekerasan, atau dengan memakai ancaman kekerasan, baik terhadap orang itu sendiri maupun orang lain". 34

Terhadap isu konstitusional tersebut, menurut MK sebagai suatu rumusan delik, kualifikasi, "Sesuatu perbuatan lain maupun perlakuan yang tak menyenangkan" tidak dapat diukur secara objektif. Seandainya pun dapat diukur maka ukuran tersebut sangatlah subjektif dan hanya berdasarkan atas penilaian korban, para penyidik, dan penuntut umum semata. Menurut MK frasa "Sesuatu perbuatan lain maupun perlakuan yang tak menyenangkan" dalam Pasal 335 ayat (1) butir 1 KUHP telah menimbulkan ketidakpastian hukum dan ketidakadilan karena memberikan peluang terjadinya kesewenang-wenangan penyidik dan penuntut umum dalam implementasinya terutama bagi pihak yang dilaporkan, sehingga justru bertentangan dengan prinsip konstitusi yang menjamin

33 Tanto Lailam, "Penafsiran Konstitusi dalam Pengujian Konstitusionalitas UndngUndang terhadap Undang-Undang Dasar 1945”, Jurnal Media Hukum, vol. 21, No. 1, Juni 2014, hal. 99.

\footnotetext{
${ }^{34}$ Mahkamah Konstitusi Republik Indonesia (a), loc. cit., hal. 40.
} 
perlindungan atas hak untuk mendapatkan kepastian hukum yang adil dalam proses penegakan hukum (Pasal 28D ayat (1) UUD 1945). ${ }^{35}$

Pendapat penulis, dalam Putusan Mahkamah Konstitusi Nomor : 1/PUUXI/2013 yang amar putusan Para Hakim menyatakan tidak berkekuatan hukum mengikat Pasal 335 ayat (1) butir 1 KUHP dan serta mengubah frasa dalam Pasal 335 ayat(1) butir 1 KUHP adalah menyimpang dari kewenangan yang seharusnya dijalankan oleh Mahkamah Konstitusi sebagai lembaga yang dibentuk untuk mengawal konstitusi. Jadi, dari uraian putusan diatas dapat penulis simpulkan bahwa Mahkamah Konstitusi tidak berwenang mengganti atau memasukkan norma baru ke dalam materi muatan (ayat, pasal, dan/atau bagian) UndangUndang yang telah dinyatakan bertentangan dengan UUD 1945 sehingga tidak mempunyai kekuatan hukum mengikat. Sesuai dengan kewengan Mahkamah Konstitusi sebagai lembaga yang hanya dapat mengabulkan permohonan dan menolak permohonan dan Mahkamah Konstitusi hanaya berfungsi sebagai lembaga penafsir konstitusi sebagai mana yang telah dijelaskan oleh penulis dalam bab sebelumnya.

\section{2) Putusan Mahkamah Konstitusi Nomor : 3/PUU-XI/2013}

Dalam putusan lain, Putusan Mahkamah Konstitusi Nomor 3/PUUXI/2013 Mahkamah Konstitusi melalui amar putusannya yaitu: Mengabulkan permohonan Pemohon untuk sebagian; yang mana Frasa "segera” dalam Pasal 18 ayat (3) Undang-Undang Nomor 8 Tahun 1981 tentang Hukum Acara Pidana bertentangan dengan Undang-Undang Dasar Negara Republik Indonesia Tahun 1945 sepanjang tidak dimaknai "segera dan tidak lebih dari 7 (tujuh) hari”; dan Frasa "segera" dalam Pasal 18 ayat (3) Undang-Undang Nomor 8 Tahun 1981 tentang Hukum Acara tidak mempunyai kekuatan hukum mengikat sepanjang tidak dimaknai "segera dan tidak lebih dari 7 (tujuh) hari". 36

Pendapat penulis, satu hal yang perlu dipahami dalam memahami atas hasil interpretasi konstitusi, adalah konteks seperti apa fakta yang dihadapkan sehingga perumusan abstraksi norma atas norma yang abstrak menghasilkan keputusan yang akan berdampak kepada sistem keadilan yang dikehendaki konstitusi. Atas dasar tersebut, maka hakim memiliki peran penting dalam

\footnotetext{
${ }^{35}$ Mahkamah Konstitusi Republik Indonesia (a), Ibid.

${ }^{36}$ Mahkamah Konstitusi Republik Indonesia (b)., loc. cit., hal. 34.
} 
menghilangkan keragu-raguan terhadap ketentuan konstitusi. Oleh karena itu, putusan Mahkamah konstitusi yang memperluas atau mempersempit makna merupakan putusan yang benar dan tidak melewati batas kewenangan mahkamah konsitusi dikarenakan Mahkamah Konstitusi berfungsi sebagai penafsir konstitusi. Dengan ini penulis berkesimpulan bahwa putusan Mahkamah Konstitusi yang telah dijelaskan diatas telah sesuai dengan fungsi Mahkamah Konstitusi sebagai lembaga penafsir konstitusi, frasa "segera" dalam rumusan Pasal 18 ayat (3) KUHAP dimaknai "segera dan tidak lebih dari 7 (tujuh) hari" dengan tujuan agar terciptanya kepastian hukum.

\section{3) Putusan Mahkamah Konstitusi Nomor : 46/PUU-XIV/2016}

Terhadap putusan Mahkamah Konstitusi Nomor 46/PUU-XIV/2016 dalam amar putusannya Hakim Mahkamah Konstitusi, "Menolak permohonan Pemohon untuk seluruhnya". ${ }^{37}$ Dalam Putusannya Mahkamah Konstitusi menyatakan menolak permohonan para pemohon untuk seluruhnya. Dengan berbagai pertimbangan Pertama, Menurut Mahkamah Konstitusi hanya pembentuk UU yang berwenang melakukannya. ${ }^{38}$ Kedua, menurut Mahkamah Konstitusi, menghilangkan frasa tertentu dan atau menambahkan pemaknaan baru terhadap suatu norma hukum pidana, yang berarti mengubah pula sifat melawan hukum perbuatan itu, tanpa melakukan penyesuaian dalam ancaman pidananya dan bentuk pengenaan pidananya tidaklah dapat diterima oleh penalaran hukum dalam merancang suatu norma hukum pidana. Ketiga, secara esensial permohonan ini menjadi berhadapan dengan asas legalitas yang wajib di terapkan secara ketat dalam hukum pidana.

Keempat, kedudukan harus dipahami MK sebagai negative legislator bukan dalam pemahaman sebagai pembentuk UU (positive legislator). Ketika menyangkut norma hukum pidana, MK di tuntut untuk tidak memasuki wilayah kebijakan pidana atau politik hukum pidana. Kelima, bahwa dalam melakukan kriminalisasi haruslah pula melihat kriteria umum yang menjadi prasyarat kriminalisasi sebuah perbuatan. Keenam, Bahwa hukum pidana adalah ultimum

\footnotetext{
${ }^{37}$ Mahkamah Konstitusi Republik Indonesia. "Putusan Nomor: 46/PUU-XIV/2016", hal. 453.

${ }^{38}$ Dian Kus Pratiwi, "Mahkamah Konstitusi Sebagai Negative Legislator Dalam Putusan Mahkamah Konstitusi No. 46/Puu-Xiv/2016 Tentang Uji Materi Pasal Kesusilaan Dalam KUHP”, (Tesis Master Universitas Islam Indonesia, 2017), hal. 38-39.
} 
remudium atau obat terakhir. Sehingga tidak semua masalah sosial tidak melulu harus diarahkan penyelesaiannya lewat kebijakan hukum pidana sebagai satusatunya obat. Artinya, hukum pidana baru akan digunakan apabila kaidah kesusilaan, kaidah kesopanan, kaidah agama, dan kaidah hukum dalam bidang atau lapangan hukum lainnya telah tidak memadai lagi. ${ }^{39}$ Ketujuh, bahwa norma pasal-pasal dalam KUHP yang dimohonkan pengujiannya tidak bertentangan dengan UUD $1945 .^{40}$

Menurut penulis pada putusan ini Mahkamah Konstitusi sudah tepat menjalankan tugasnya. Pada putusan Mahkamah Konsitutis Nomor 46/PUUXIV/2016 ini mahkamah telah benar dalam menerapkan hukum, bahwa Mahkamah tidak berwenang mengubah frasa dalam peraturan perundangundangan yang dianggap bertentangan dengan Undang-Undang Dasar 1945. Sama halnya dengan pada putusan Nomor 1/PUU-XI/2003 yang telah dibahas sebelumnya oleh penulis, dalam hal mengubah frasa, menambahkan maupun mengurangi frasa yang terdapat dalam suatu Undang-Undang bukanlah kewenangan dari Mahkamah Konstitusi.

\section{Kewenangan Mahkamah Konstitusi dalam Menguji Formil Undang-undang terhadap Undang-Udang Dasar 1945 (UUD 1945)}

Hak menguji formal adalah wewenang untuk menilai suatu produk legislatif seperti undang-undang, misalnya terjelma melalui cara-cara (procedur) sebagaimana telah ditentukan/diatur dalam peraturan perundang-undangan yang berlaku ataukah tidak. ${ }^{41}$ Menurut Jimly Ashiddiqie, pengujian formal dapat mencakup: ${ }^{42}$ 1) pengujian atas pelaksanaan tata cara atau prosedur pembentukan peraturan perundang-undangan, baik dalam pembahasan maupun dalam pengambilan keputusan atas rancangan suatu peraturan perundang-undangan menjadi peraturan perundang-undangan; 2) pengujian atas bentuk, format atau

${ }^{39}$ Mahkamah Konstitusi Republik Indonesia. "Putusan Nomor: 46/PUU-XIV/2016"., op.cit.

40 Agus Satria Adi Husada dan Hananto Widodo, "Analisis Yuridis Kewenangan Mahkamah Konstitusi Terhadap Putusan Nomor 46/Puu-Xiv/2016 Sebagai Negative Legislator”, Jurnal Novum, vol. $\quad 3, \quad$ No. 1 , 2018,http://jurnalmahasiswa.unesa.ac.id/index.php/novum/article/view/25831/23673, diakses pada tanggal 16 Desember 2018

${ }^{41}$ Ali Marwan Hsb, Konsep Judicial Review dan Pelembagaannya di Berbagai Negara, (Malang: Setara Press, 2017), hal. 3.

42 Jimy Ashiddiqie, op. cit., hal. 42-42. 
struktur peraturan perundang-undangan; 3) pengujian yang berkenaan dengan keberwenangan lembaga yang mengambil keputusan dalam proses pembentukan peraturan perundang-undangan; dan 4) pengujian atas hal-hal lain yang tidak termasuk pengujian materiil. Menurut Gerhard van derSchyff sebagaimana dikutip oleh Bayu Dwi Anggono, tujuan dari pengujian formal (legalitas) adalah untuk memastikan diikutinya seluruh prosedur pembentukan undang-undang yang tepat oleh legislatif. ${ }^{43}$

Pengujian formal secara singkat disebut dalam Pasal 51 ayat (3) huruf a UU Mahkamah Konstitusi, yang menyatakan pemohon wajib menguraikan dengan jelas bahwa pembentukan undang-undang tidak memenuhi ketentuan berdasarkan UUD 1945. Pengujian secara formal akan melakukan pengujian atas dasar kewenangan dalam pembentukan undang-undang dan prosedur yang harus ditempuh dari tahap drafting sampai dengan pengumuman dalam Lembaran Negara yang harus menuruti ketentuan yang berlaku untuk itu. Dalam Pasal 4 Peraturan Mahkamah Konstitusi (PMK) No. 06/PMK/2005 tentang Pedoman Beracara Pengujian Undang-Undang terhadap Undang-Undang Dasar 1945 di sebutkan bahwa pengujian formal adalah pengujian undang-undang berkenan dengan bentuk dan pembentukan UUD 1945 yang meliputi pembahasan, pengesahan, pengundangan, dan pemberlakuan. ${ }^{44}$

M. Fajrul falaakh mengemukakan bahwa hak menguji formal (prosedural) untuk menentukan benar tidaknya cara menerbitkan suau peraturan perundangundangan, atau wewenang untuk menilai apakah suatu produk hukum telah memenuhi semua prosedur (procedure) pembentukannya sebagaimana telah ditentukan/diatur dalam peraturan perundang-undangan yang berlaku ataukah tidak. $^{45}$

Aspek format, formal, dan formalisasi itu sendiri cukup luas cakupannya, yaitu mulai dari proses persiapan berupa perancangan sampai pada tahap pengundangan dan bahkan pemberlakuan suatu norma menjadi norma yang mengikat untuk umum. Dalam pandangannya bahwa pengujian formil tidak

\footnotetext{
${ }^{43}$ Ali Marwan Hsb, op. cit.

${ }^{44}$ Bachtiar, op.cit., hal. 134.

${ }^{45}$ Tanto Lailam, "Analisis Praktik Pengujian Formil Undang-Undang terhadap UndangUndang Dasar 1945”, Pranata Hukum, vol. 6, No. 2, Juli 2011, hal. 147-148.
} 
mencakup proses pembentukan undang-undang dalam arti sempit, tetapi juga mencakup pengujian mengenai aspek bentuk undang-undang, dan pemberlakuan undang-undang yang tidak tergolong sebagai bagian dari proses pembentukan undang-undang, juga dijelaskan bahwa pengujian formil berkaitan dengan soalsoal prosedural dan berkenaan dengan legalitas kompetensi institusi yang membentuknya. Pengertian yang dapat dikembangkan dalam rangka pemahaman terhadap konsepsi pengujian formil itu bersifat sangan kompleks, secara umum kriteria yang dapat dipakai untuk menilai suatu objek pengujian (undang-undang terhadap Undang-Undang Dasar 1945) dari segi formalnya (formele toetsing) adalah sejauh mana peraturan diatas ditetapkan dalam bentuk yang tepat (appopriate form), oleh institusi yang tepat (appopriate institution) dan menurut prosedur yang tepat (appopriate procedure). ${ }^{46}$

\section{Berikut Perbandingan Putusan Mahkamah Konstitusi dalam Menguji Formil:}

a) Putusan Mahkamah Konstitusi Nomor : 27/PUU-VII/2009

Dalam pengujian formil dalam Putusan Mahkamah Konstitusi Nomor 27/PUUVII/2009, Mahkamah Konstitusi menimbang bahwa Proses pembentukan UU yang dimohonkan pengujiannya oleh para pemohon telah melanggar ketentuan formil pengambilan keputusan pada waktu itu, yaitu tata tertib DPR Nomor 08/DPR RI/2005- 2006 dan Pasal 20 UUD 1945 sehingga cacat secara prosedural.MK berpendapat walaupun dalam proses pembentukkannya terdapat cacar prosedural, namun untuk dinyatakan bahwa undang-undang tersebut tidak mempunyai kekuatan hukum mengikat, Mahkamah perlu mempertimbangkan asas manfaat untuk tercapainya tujuan hukum, pada akhirnya MK memutuskan bahwa UU yang dimohonkan pengujian tersebut tidak perlu dinyatakan sebagai UU yang tidak mempunyai kekuatan hukum mengikat artinya UU tersebut tetap mempunyai kekuatan hukum berlaku. Atas pertimbangan tersebut dan demi asas manfaat untuk tercapainya tujuan hukum. Pada akhirnya MK memutuskan bahwa UU yang dimohonkan pengujian tersebut tidak perlu dinyatakan sebagai UU yang 
tidak mempunyai kekuatan hukum mengikat; artinya UU a quo tetap mempunyai kekuatan hukum berlaku. ${ }^{47}$

\section{b) Putusan Mahkamah Konstitusi Nomor : 018/PUU-I/2003}

Dalam Putusan Mahkamah Konstitusi Nomor 018/PUU-I/2003, Pemohon mengajukan Permohonan Pengujian Undang-undang Nomor 45 Tahun 1999 tentang Pembentukan Propinsi Irian Jaya Tengah, Propinsi Irian Jaya Barat, Kabupaten Paniai, Kabupaten Mimika, Kabupaten Puncak Jaya, dan Kota Sorong, diubah dengan Undang-undang Nomor 5 Tahun 2000 tentang Perubahan atas Undang-undang Nomor 45 Tahun 1999 tentang Pembentukan Propinsi Irian Jaya Tengah, Propinsi Irian Jaya Barat, Kabupaten Paniai, Kabupaten Mimika, Kabupaten Puncak Jaya, dan Kota Sorong, bertentangan dengan Pasal 18B Undang-Undang Dasar Negara Republik Indonesia Tahun 1945. ${ }^{48}$ Pasal 50 Undang-undang Nomor 24 Tahun 2003 tentang Mahkamah Konstitusi, menyatakan "Undang-undang yang dapat dimohonkan untuk diuji adalah undangundang yang diundangkan setelah perubahan Undang-Undang Dasar Negara Republik Indonesia". Penjelasan pasal tersebut, menyatakan: "Yang dimaksud dengan "setelah perubahan Undang-Undang Dasar Negara Republik Indonesia Tahun 1945" adalah perubahan pertama Undang-Undang Dasar Negara Republik Indonesia Tahun 1945 pada tanggal 19 Oktober $1999 .{ }^{49}$

Menurut penulis tata cara pembuatan suatu undang-undang harus mengikuti prosedur yang telah diatur dalam undang-undang Nomor 12 Tahun 2011 tentang Pembentukan Peraturan Perundang-Undangan. Sehingga, dalam proses pembentukan, pengundangan maupun pemberlakuan undang-undang dapat berjalan sesuai tanggal yang ditetapkan jika prosedurnya mengikuti ketentuan undang-undang Nomor 12 Tahun 2011. Seharusnya pula dalam undang-undang itu ditegaskan bahwa dengan berlakunya UU No. 12 Tahun 2001 tersebut, maka UU sebelumnya, yaitu UU Nomor 45 Tahun 1999 tidak diberlakukan lagi,

\footnotetext{
${ }^{47}$ Jorawati Simarmata, "Pengujian Undang-Undang Secara Formil Oleh Mahkamah Konstitusi: Apakah Keniscayaan? (Perbandingan Putusan Mahkamah Konstitusi Nomor 79/PUUXII/2014 dan Putusan Mahkamah Konstitusi Nomor 27/PUU-VII/2009) (Judicial Review Of The Law In Formal By The Constitutional Court: Is It Certainity? (Comparation On The Constitutional Court's Decision Number 79 / PUU-XII / 2014 and 27 / PUU-VII / 2009)", Jurnal Legilasi Indonesia, vol. 14, No. 1, Maret 2017, hal. 47.

${ }^{48}$ Mahkamah Konstitusi Republik Indonesia, "Putusan Nomor : 018/PUU-I/2003”, hal. 2.

${ }^{49}$ Ibid.
} 
sehingga tidak menimbulkan kesimpangsiuran dan ketidakpastian hukum sebagai akibat adanya dualisme hukum di lapangan.

Putusan Mahkamah Konstitusi tentunya masing-masing memiliki konsekuensi tersendiri. Misalkan putusan yang amarnya mengabulkan permohonan, berimbas pada batalnya suatu norma dan tidak memiliki kekuatan hukum mengikat. Dengan sendirinya, putusan tersebut tidak dapat dilepaskan dari asas erga omnes yang memiliki kekuatan mengikat secara hukum terhadap seluruh komponen bangsa, sehingga semua pihak harus tunduk dan taat melaksanakan putusan tersebut. Namun demikian putusan MK terkadang diragukan efektivitasnya karena ada kecederungan tidak dipatuhi dan diabaikan oleh addressat putusan. Padahal menurut Maruarar Siahaan efektifitas checks and balances dapat dilihat dari dilaksanakan atau tidaknya bunyi putusan MK oleh pembuat undang-undang. Kepatuhan dalam implementasi putusan MK itu dapat pula menjadi ukuran apakah UUD 1945 yang menjadi hukum tertinggi dalam negara sungguh-sungguh menjadi hukum yang hidup. ${ }^{50}$

Di samping soal proses pengambilan keputusan dan dimensi keadilan di dalamnya, salah satu titik krusial dan problem serius dalam pembicaraan mengenai putusan pengadilan adalah terkait dengan implikasi dan eksekusi atau implementasi putusan tersebut. Pada banyak kesempatan, putusan pengadilan kerapkali mendapatkan tentangan, baik dari adressat putusan maupun aktor-aktor non yudisial lainnya ketika hendak diimplementasikan. Hal tersebut dijumpai di banyak negara, termasuk dialami pula oleh putusan-putusan pengadilan di Indonesia Pun demikian, putusan MK Indonesia kerapkali dihadang oleh kerumitan problem di tataran implementasi. ${ }^{51}$

Pada dasarnya Putusan Mahkamah Konstitusi atas pengujian undangundang memperoleh kekuatan hukum tetap sejak selesai diucapkan/dibacakan, sehingga pelaksanaan putusan Mahkamah Konstitusi dilaksanakan sejak selesai dibacakan putusan yang bersangkutan. Meskipun Putusan Mahkamah Konstitusi mempunyai kekuatan hukum mengikat sejak selesai dibacakan, namun tidak semua putusan Mahkamah Konstitusi yang mengabulkan permohonan Pemohon

\footnotetext{
50 Anies Prima Dewi, "Problematika Putusan Mahkamah Konstitusi Dalam Pengujian Undang-Undang”, Jurnal Ilmiah Mandala Education,vol.3, No. 2, Oktober 2017, hal. 243-244.

${ }^{51}$ Ibid., hal. 695.
} 
dapat langsung dilaksanakan (implementing), karena untuk pelaksanaan putusan Mahkamah Konstitusi tersebut masih memerlukan tindak lanjut dengan pembentukan undang-undang baru atau undang-undang perubahan. Inilah putusan yang disebut dengan non-self implementing. Dikatakan demikian karena putusan tersebut mempengaruhi norma-norma lain dan memerlukan revisi atau pembentukan undang-undang baru atau peraturan yang lebih operasional dalam pelaksanannya. Dengan kata lain, putusan ini tidak bisa serta merta dilaksanakan (tidak selfimplementing) tanpa adanya undang-undang baru karena menimbulkan kekosongan hukum. ${ }^{52}$

\section{PENUTUP}

\section{Kesimpulan}

Mahkamah Konstitusi merupakan negative legislator, lembaga yang kewenangannya menyatakan muatan materi, isi, pasal atau ayat yang terdapat dalam suatu undang-undang bertentangan dengan UUD 1945. Apabila Mahkamah Konstitusi menyatakan suatu Undang-Undang bertentangan dengan UUD 1945, maka sesusai dengan pasal 20 ayat (1) UUD 1945 tugas dari lembaga legislatif yakni DPR yang mempunyai kewenangan merevisi undang-undang tersebut karena lembaga DPR yang memegang kekuasaan membentuk undang-undang sesuai dengan fungsinya sebagai positive legislator. Pasal 57 ayat (2a) huruf b dan huruf c UU Nomor 8 Tahun 2011 Tentang Mahkamah Konstitusi menyatakan bahwa Putusan Mahkamah Konstitusi tidak memuat perintah kepada pembuat undang-undang dan rumusan norma sebagai pengganti norma dari undang-undang yang dinyatakan bertentangan dengan UUD 1945 hal ini sejalan dengan Pasal 36 PMK tahun 2005. Dalam peraturan tersebut telah jelas diterangkan bahwa mahkamah konstitusi hanya berfungsi sebagai negative legislator, seperti dalam putusan Mahkamah Konstitusi Nomor 46/PUU-XIV/2016 yang dibahas sebelumnya.

Selain fungsi Mahkamah Konstitusi sebagai negative legislator, Mahkamah Konstitusi juga berfungsi sebagai Penafsir final dari Konstitusi. Dalam perkembangannya Mahkamah Konstitusi menafsirkan undang-undang yang masih abstrak dan sudah tidak sesuai dengan perkembangan zaman, putusan Mahkmah

\footnotetext{
52 Anies Prima Dewi., op. cit, hal. 245.
} 
Konstitusi dalam menafsirkan makna dari suatu undang-undang merupakan bentuk dari putusan yang adil demi kepastian hukum, putusan seperti ini tercermin dalam putusan Nomor 3/PUU-XII/2013 tentang penafsiran frasa "segera" dalam Pasal 18 ayat 3 KUHAP tentang Penangkapan.

Dalam pengujian formil telah ditetapkan dalam Pasal 51A ayat (3) UU Nomor 8 Tahun 2011 Tentang Mahkamah Konstitusi pegujian harus berdasarkan pada peraturan perundang-undangan yang mengatur tata cara pembentukan peraturan perundang-undangan yang mana peraturan tersebut diatur dalam UUD 1945 dan UU Nomor 12 tahun 2011 Tentang Pembentukan Peraturan PerundangUndangan, dalam peraturan tersebut asas keterbukaan merupakan syarat yang harus dipenuhi dalam pembuatan undang-undang. Namun, dalam proses pembentukan undang-undang masih belum tercermin oleh lembaga pembentuk undang-undang.

\section{Saran}

Putusan Mahkamah Konstitusi dalam pengujian materiil undang-undang terhadap Undang-Undang Dasar 1945 haruslah sejalan dengan peraturan yang mengaturnya, yaitu UU Nomor 8 Tahun 2011 tentang Mahkamah Konstitusi dan PMK Nomor 06 Tahun 2005. Diharapkan kedepannya peraturan yang mengatur uji formil dapat direvisi kembali sehingga lembaga yang berwenangan membuat undang-undang lebih memperhatikan proses pembuatan undang-undang yang transparan dan terbuka sehingga informasi maupun proses tersebut dapat diketahui oleh masyarakat. 


\section{DAFTAR PUSTAKA}

\section{Buku}

Arto, Mukti. Konsepsi Ideal Mahkamah Agung: Redefenisi Peran dan Fungsi Mahkamah Agung untuk Membangun Indonesia Baru. Yogyakarta: Pustaka Pelajar, 2001.

Asshiddiqie, Jimly. Setengah Abad Jimly Asshiddiqie, Konstitusi dan Semangat Kebangsaan. Jakarta: PT. Sumber Agung, 2006.

Ashiddiqie, Jimly. Hukum Acara Pengujian Undang-undang. Jakarta: Sinar Gratifika, 2012.

Gaffar, Janedri M. Hukum Acara Mahkamah Konstitusi. Cet. I. Jakarta: Sekretariat Jendera dan Kepaniteraan MKRI, 2011.

Harun, Refli. Menjaga Denyut Konstitusi (Refleksi Satu Tahun Mahkamah Konstitusi). Jakarta: Konstitusi Press, 2004.

Isra, Saldi. Pergeseran Fungsi Legislasi: Menguatnya Model Legislasi Parlementer Dalam Sistem Presidensial Indonesia. Jakarta: Rajawali Press, 2010.

Latief, Abdul. Fungsi Mahkamah Konstitusi: Upaya Mewujudkan Negara Hukum Demokrasi. Yogyakarta: Total Media, 2009.

Mahfud, Moh. Perdebatan Hukum Tata Negara Pasca Amandemen Konstitusi. Jakarta: Rajawali Press, 2011.

Mahfud MD, Moh. Konstitusi dan Hukum dalam Kontroversi Isu. Jakarta: Rajawali Pers, 2009.

Marwan Hsb, Ali. Konsep Judicial Review dan Pelembagaannya di Berbagai Negara. Malang: Setara Press, 2017.

Marzuki, Peter Mahmud. Penelitian Hukum. Jakarta: Prenadamedia Group, 2016.

Palguna, I Dewa Gede. Mahkamah Konstitusi: dasar pemikiran, kewenangan, dan perbandingan dengan negara lain. Sekretariat Jenderal MK RI:Konstitusi Press (Konpress), 2018.

Soebechi, Imam. Hak Uji Materiil. Cet. 1. Jakarta: Sinar Gratifika, 2016.

Soekanto, Soerjono. Pengantar Penelitian Hukum. Cet 3. Jakarta : Universitas Indonesia, 2014.

Soemantri, Sri. Hak Menguji Material di Indonesia. Bandung: Penerbit Alumni,1986. 


\section{Peraturan dan Putusan}

Undang-Undang Dasar Negara Republik Indonesia Tahun 1945.

Undang-Undang Tentang Perubahan atas Undang-Undang Nomor 24 Tahun 2003 Tentang Mahkamah Konstitusi. UU Nomor 8 Tahun 2011.

Peraturan Mahkamah Konstitusi Tentang Pedoman Beracara Perkara Pengujian Undang-Undang”. PMK Nomor : 06/Pmk/2005.

Mahkamah Konstitusi Republik Indonesia. "Putusan Nomor: 1/PUU-XI/2013".

Mahkamah Konstitusi Republik Indonesia. "Putusan Nomor: 3/PUU-XI/2013".

Mahkamah Konstitusi Republik Indonesia. "Putusan Nomor: 46/PUU-XIV/2016".

Mahkamah Konstitusi Republik Indonesia. "Putusan Nomor: 27/PUU-VII/2009”.

Mahkamah Konstitusi Republik Indonesia, "Putusan Nomor : 018/PUU-I/2003".

\section{Artikel dan Jurnal}

Anies Prima Dewi. "Problematika Putusan Mahkamah Konstitusi Dalam Pengujian Undang- Undang”. Jurnal Ilmiah Mandala Education. vol.3. No. 2. Oktober 2017.

Anonimous. "Eksistensi Lembaga Negara, Berdasarkan UU Negara RI Tahun 1945”. Jurnal Legislasi. vol. 4. no. 3. Direktorat Jenderal Peraturan Perundang-undangan Departemen Hukum dan HAM RI, Jakarta 2007.

Bambang Sutiyoso. "Putusan Mahkamah Konstitusi dan Implikasinya Terhadap Pencari Keadilan”. Jurnal Hukum. vol. 3. No. 15. Juli 2008.

Dian Kus Pratiwi. "Mahkamah Konstitusi Sebagai Negative Legislator Dalam Putusan Mahkamah Konstitusi No. 46/Puu-Xiv/2016 Tentang Uji Materi Pasal Kesusilaan Dalam KUHP". (Tesis Master Universitas Islam Indonesia, 2017).

Eko Supriyanto. "Kedudukan Naskah Akademik dalam Penafsiran Ketentuan Ketentuan dalam Undang-Undang". Yuridika, vol. 31. No. 3. September 2016.

Feri Amsari. "Satjipto Rahardjo dalam Jagat Ketertiban Hukum Progresif" Jurnal Konstitusi. vol. 6. No. 2. Juli 2009.

Jorawati Simarmata. "Pengujian Undang-Undang Secara Formil Oleh Mahkamah Konstitusi: Apakah Keniscayaan? (Perbandingan Putusan Mahkamah Konstitusi Nomor 79/PUU-XII/2014 dan Putusan Mahkamah Konstitusi Nomor 27/PUU-VII/2009) 
Muhammad Mahrus Ali. "Konstitusional dan Legalitas Norma dalam Pengujian Undang-Undang Terhadap Undang-Undang Dasar 1945". Jurnal Konstitusi. vol. 12. No. 1. Maret 2015.

Nanang Sri Darmani. "Kedudukan dan Wewenang Mahkamah Konstitusi dalam Sistem Hukum Ketatanegaraan Indonesia”. Jurnal Pembaharuan Hukum. vol. II. No. 2. Mei Agustus 2015.

Syawaluddin Hanafi. "Kewenangan Mahkamah Konstitusi dalam Menafsir Undang-Undang Dasar Negara Republik Indonesia Tahun 1945”. Ekspose. vol. XXVI. No. 1. Januari-Juni 2017.

Tanto Lailam. "Penafsiran Konstitusi dalam Pengujian Konstitusionalitas Undang-Undang terhadap Undang-Undang Dasar 1945". Jurnal Media Hukum. vol. 21, No. 1. Juni 2014.

Tanto Lailam. "Analisis Praktik Pengujian Formil Undang-Undang terhadap Undang-Undang Dasar 1945”. Pranata Hukum. vol. 6. No. 2. Juli 2011

\section{Internet}

Dimas Indra Swadana, "Implikasi Yuridis dari Perubahan Pasal 335 KUHP Ayat (1) butir ke-1 tentang Perbuatan tidak Menyenangkan Oleh Mahkamah Konstitusi Berdasarkan Putusan Nomor: 1/Puu-Xi/2013 Tentang Penghapusan Frase Perbuatan Yang Tidak Menyenangkan”. Jurnal Hukum http://hukum.studentjournal.ub.ac.id/index.php/hukum/article/iew/770/757. diakses tanggal 10 Desember 2018.

Agus Satria Adi Husada dan Hananto Widodo, "Analisis Yuridis Kewenangan Mahkamah Konstitusi Terhadap Putusan Nomor 46/Puu-Xiv/2016 Sebagai Negative Legislator". Jurnal Novu. vol. 3. No. 1. 2018 http://jurnalmahasiswa.unesa.ac.id/index.php/novum/article/via/25831/236 73. diakses pada tanggal 16 Desember 2018 